\title{
PENURUNAN KADAR TIMBAL (PB) PADA KERANG DARAH DENGAN MENGGUNAKAN ASAM
}

\author{
Christine Abadiana **) dan Indah Nurhayati *)
}

\begin{abstract}
Abastrak
Peningkatan kadar logam berat timbal $(\mathrm{Pb}$ ) pada air laut akan diikuti dengan peningkatan kadar logam berat pada biota laut. Dengan melalui rantai makanan logam Pb akan masuk ke dalam tubuh manusia. Mengkonsumsi kerang yang tercemar $\mathrm{Pb}$ secara terus-menerus maka akan terjadi akumulasi $\mathrm{Pb}$ dalam tubuh manusia. Logam timbal ini pada dasarnya toksik pada organ-organ tubuh. Penelitian bertujuan untuk mengetahui kadar $\mathrm{Pb}$ pada cangkang dan daging kerang darah, mengkaji pengaruh jenis asam (asetat atau sitrat $25 \%$ ), serta lama perendaman (1 dan 3 jam) terhadap penurunan kadar Pb pada kerang darah. Penelitian ini juga bertujuan untuk memberikan gambaran konsentrasi pencemaran Pb oleh limbah dari cangkang kerang darah dan penggunaan media larutan asam ke lingkungan. Kerang darah yang digunakan sebagai sampel dalam penelitian ini adalah kerang darah dengan ukuran cangkang antara 3 - $4 \mathrm{~cm}$, yang diambil dari Pantai Kenjeran Surabaya Jawa Timur. Dari penelitian ini dapat disimpulkan kadar Pb mula - mula pada cangkang kerang darah, yakni 0.502 ppm sedangkan pada daging kerang sebesar 0.217 ppm. Setelah dilakukan perendaman menggunakan asam asetat atau asam sitrat $25 \%$ kadar $\mathrm{Pb}$ mengalami penurunan. Perendaman dengan asam asetat dapat menurunkan kadar $\mathrm{Pb}$ yang lebih besar pada perendaman cangkang kerang. Semakin lama waktu perendaman semakin berkurang kadar $\mathrm{Pb}$ pada cangkang dan daging kerang. Cangkang kerang dan air limbah perendaman berpotensi mencemarkan lingkungan.
\end{abstract}

Kata Kunci: Asam asetat, asam sitrat, Kerang Darah, Timbal (Pb).

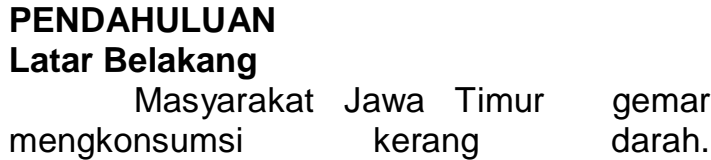
Berdasarkan data yang dihimpun oleh Dinas Perikanan dan Kelautan Provinsi Jawa Timur tahun 2007, kerang darah merupakan salah satu jenis kerang yang paling banyak dibudidayakan masyarakat (Nontji, 2002). Khususnya di Surabaya, kerang darah ini banyak dibudidayakan atau dijual di daerah Pantai Kenjeran Surabaya. Pantai Kenjeran telah tercemar jenis logam berat timbal $(\mathrm{Pb})$. Hasil penelitian Bajuri (2003) menunjukkan bahwa rata - rata kadar $\mathrm{Pb}$ pada daging kupang awung ( kelompok kerang - kerangan ) yang berasal dari Pantai Kenjeran, yaitu sebesar $1.813 \mathrm{ppm}$. Nilai tersebut cukup tinggi dan hampir melebihi Nilai Ambang Batas (NAB) pencemaran $\mathrm{Pb}$ pada makanan, karena batas yang direkomendasikan oleh World Health Organization (WHO) untuk kadar $\mathrm{Pb}$ pada makanan yang dikonsumsi manusia adalah 0.1 - 2 ppm (Darmono, 2001).

Kerang memiliki sifat infauna atau semi - infauna yang mendiami habitat berpasir dan berlumpur di kawasan pesisir sebagai penyusun komunitas macrozoobentos. Kerang juga merupakan salah satu komponen utama di sedimen lunak di kawasan pesisir (Hendrickx, 2007). Kerang mempunyai sifat lambat untuk dapat menghindarkan diri dari pengaruh polusi. Kerang mempunyai toleransi tinggi terhadap konsentrasi logam tertentu. mobilitas kerang rendah, menetap di dalam suatu habitat, yaitu di sedimen atau dasar laut, karenanya proses biokonsentrasi dan bioakumulasi dapat terjadi secara lebih intensif. Namun Hewan akuatik, diantaranya kerang tersebut, memiliki kemampuan mengakumulasi logam berat hingga batas yang tidak menyebabkan efek toksik terhadap dirinya sendiri. Kerang darah dapat menjaring logam berat seperti $\mathrm{Pb}$. Kerang darah hidup dalam lumpur, bahkan mampu memakan sedimen air laut, karenanya proses biokonsentrasi dan bioakumulasi dapat terjadi secara lebih intensif.

\footnotetext{
**) Mahasiswa Teknik Lingkungan

*) Dosen Teknik Lingkungan

Universitas PGRI Adi Buana Surabaya
} 
Akumulasi kadar $\mathrm{Pb}$ dari kerang darah di dalam tubuh manusia pada akhirnya toksik pada organ - organ tubuh tertentu, seperti dalam sistem hemopoietik, saraf pusat dan tepi, ginjal, gastro intestinal, kardiovaskuler, reproduksi, serta indokrin.

$\mathrm{Pb}$ yang masuk ke dalam badan perairan adalah sebagai dampak dari aktifitas manusia. Diantaranya adalah air buangan (limbah) dari industri yang berkaitan dengan $\mathrm{Pb}$, air buangan dari pertambangan bijih timah hitam dan buangan sisa industri baterai. Buangan tersebut akan jatuh pada jalur perairan, seperti anak anak sungai untukkemudian akan dibawa terus menuju lautan ( Palar, 2004).

Umumnya industri yang membuang limbah masih mengandung $\mathrm{Pb}$ akan merusak tata lingkungan perairan yang dimasukinya sehingga menjadikan sungai dan alurnya tercemar. Konsentrasi $\mathrm{Pb}$ yang mencapai 188 ppm, dapat membunuh ikan. Hal tersebut dapat terjadi bila suatu badan perairan telah kemasukan senyawa atau ion ion $\mathrm{Pb}$, sehingga jumlah $\mathrm{Pb}$ yang ada pada badan perairan melebihi konsentrasi yang semestinya (Palar, 2004). Daya racun $\mathrm{Pb}$ di dalam tubuh diantaranya disebabkan oleh penghambatan enzim oleh ion $\mathrm{Pb}^{2+}$. Enzim yang diduga dihambat adalah yang diperlukan untuk pembentukan hemoglobin. Penghambatan tersebut disebabkan terbentuknya ikatan yang kuat (ikatan kovalen) antara $\mathrm{Pb}^{2+}$ dengan grup sulfur yang terdapat di dalam asam - asam amino dari enzim tersebut. $\mathrm{Pb}$ yang tertinggal di dalam tubuh, baik dari udara maupun melalui makanan / minuman, akan mengumpul terutama didalam skeleton ( 90 $95 \%$ ). Tulang berfungsi sebagai tempat pengumpulan $\mathrm{Pb}$.

Larutan asam asetat (cuka) $25 \%$ tidak berbahaya, namun konsumsi asam asetat yang lebih pekat adalah berbahaya bagi manusia maupun hewan. Hal itu dapat menyebabkan kerusakan pada sistem pencernaan dan perubahan yang mematikan pada keasaman darah. Asam asetat mempunyai kemampuanm mengikat logam (chelating agent).

Asam sitrat merupakan asam organik lemah yang ditemukan pada daun dan buah tumbuhan genus Citrus (jerukjerukan). Senyawa ini merupakan bahan pengawet yang baik dan alami, dapat digunakan sebagai penambah rasa masam padamakanan dan minuman ringan. Selain itu, asam sitrat dapat digunakan untuk mengikat logam, karena dapat mengkatalis oksidasi komponen cita rasa dan warna. Asam sitrat aman digunakan pada makanan oleh semua badan pengawasan makanan nasional dan internasional. Asam sitrat secara alami terdapat pada semua jenis makhluk hidup, dan kelebihan asam sitrat dengan mudah dimetabolisme dan dihilangkan dari tubuh. Asam sitrat mempunyai kemampuan mengikat logam (chelating agent).

Salah satu cara yang mudah dilakukan masyarakat konsumen hasil laut (kerang) untuk mengurangi masuknya logam berat $\mathrm{Pb}$ ke dalam tubuh, yaitu dengan perendaman larutan asam asetat atau sitrat $25 \%$ dalam periode waktu tertentu. Asam asetat dan sitrat ini mempunyai kemampuan mengikat logam (chelating agent).

Hasil penelitian terdahulu menunjukkan bahwa perendaman daging kerang bulu dengan larutan asam asetat $25 \%$, dengan waktu perendaman 1 dan 2 jam, dapat menurunkan kadar logam berat $\mathrm{Cd}$ berturut - turut sebesar $63.2 \%$ dan 77.72 $\%$. Perendaman dengan larutan ini efektif menurunkan kadar logam berat selama 1 jam (Sari dan Keman, 2005). Perendaman daging ikan bandeng dengan larutan asam asetat $25 \%$, juga diketahui dapat menurunkan kadar logam berat $\mathrm{Pb}$ cukup signifikan (Imaduddin dkk, 2000). Sedangkan perendaman daging kupang awung dengan larutan asam sitrat $25 \%$, dengan waktu perendaman 1, 2 dan 3 jam, dapat menurunkan kadar logam berat $\mathrm{Pb}$ berturut turut sebesar $61.73 \%, 73.88 \%$, dan 93.32 $\%$. Perendaman dengan larutan ini efektif menurunkan kadar logam berat selama 3 jam (Rahardhiman, 2008).

Berdasarkan latar belakang di atas, maka penulis tertarik untuk melakukan penelitian tentang penurunan kadar $\mathrm{Pb}$ dalam kerang darah dengan cara perendaman larutan asam. Adapun penelitian bertujuan untuk mengetahui kadar $\mathrm{Pb}$ pada cangkang dan daging kerang darah, mengetahui pengaruh jenis asam, serta lama perendaman terhadap penurunan kadar $\mathrm{Pb}$ pada kerang darah. Penelitian ini juga dapat memberikan gambaran konsentrasi pencemaran $\mathrm{Pb}$ yang berasal dari limbah cangkang kerang darah dan limbah cair larutan asam sebagai media perendaman yang dibuang ke lingkungan. 


\section{METODE PENELITIAN}

Penelitian ini dilakukan di Balai Besar Laboratorium Kesehatan (BBLK) Surabaya pada bulan Nopember 2012.

\section{Variabel penelitian}

Variabel bebas dalam penelitian ini adalah adalah letak organ

(cangkang atau daging), jenis larutan asam (asam asetat atau sitrat $25 \%$ ), serta lama perendaman (1 dan 3 jam).

Materi penelitian

Alat dan bahan yang digunakan dalam penelitian ini adalah Atomic Absorbtion Spectrophotometry(AAS), kerang darah, larutan asam asetat $25 \%$, larutan asam sitrat $25 \%$, Beacker glass, Stopwatch, larutan asam asetet $25 \%$ dan asam sitrat $25 \%$.

\section{Sampel}

Sampel kerang yang digunakan dalam penelitian ini adalah kerang darah yang berasal dari pantai Kenjeran Surabaya Jawa Timur. Kerang darah yang digunakan adalah berukuran $3-4 \mathrm{~cm}$, Kondisi cangkang masih tertutup, belum mengalami proses pengolahan (mentah), dan belum dicuci.

\section{Tahapan penelitian}

1. Kerang darah dipisahkan antara daging dan cangkangnya

2. Daging kerang darah yang belum direndah menggunakan asam dianalisis kadar Pbnya terlebih dahulu menggunakan AAS.
3. Daging kerang darah direndam dalam larutan asam yang divariasikan (asam asetat $25 \%$ atau asam sitrat $25 \%$ ) selama waktu perendaman yang divariasikan ( 1 jam atau 3 jam)

4. Daging kerang ditiriskan kemudian dianalisis kadar Pbnya menggunakan AAS.

5. Larutan perendaman dianalisis kadar Pbnya menggunakan AAS

6. Cangkang kerang dihancurkan sampai menyerupai tepung.

7. Tepung cangkang sebelum direndam dalam larutan asam dianalisis kadar Pbnya terlebih dahulu.

8. Tepung cangkang direndam dalam larutan asam yang divariasikan (asam asetat $25 \%$ atau asam sitrat $25 \%$ ) selama waktu perendaman yang divariasikan ( 1 jam atau 3 jam)

9. Tepung disaring menggunakan kertas saring dan dianalisis kadar pbnya menggunakan AAS

10. Larutan perendaman dianalisis kadar Pbnya menggunakan AAS

Analisis Data

Data yang diperoleh disajikan dalam bentuk grafik dan tabel.

\section{HASIL DAN PEMBAHASAN}

Kadar logam berat $\mathrm{Pb}$ pada cangkang dan daging kerang dapat dilihat pada tebal 1 dan tabel 2 di bawah ini

Tabel 1 Kadar Pb pada Cangkang Kerang Darah

Kadar Pb pada Cangkang Kerang Darah (ppm)

Waktu Perendaman

\begin{tabular}{|c|c|c|c|c|c|c|c|}
\hline \multirow[t]{2}{*}{ No. } & \multirow{2}{*}{$\begin{array}{c}\text { larutan } \\
\text { Perendaman }\end{array}$} & \multirow[t]{2}{*}{ Replikasi } & \multirow{2}{*}{$\begin{array}{c}\text { Sebelum } \\
\text { Perendaman } \\
\text { ( Kadar awal) }\end{array}$} & \multicolumn{2}{|c|}{$1 \mathrm{Jam}$} & \multicolumn{2}{|c|}{3 Jam } \\
\hline & & & & $\begin{array}{l}\text { Kadar } \\
\text { akhir }\end{array}$ & $\begin{array}{l}\text { Efisiensi } \\
\text { Penurunan } \\
(\%)\end{array}$ & $\begin{array}{l}\text { Kadar } \\
\text { akhir }\end{array}$ & $\begin{array}{c}\text { Efisiensi } \\
\text { Penurunan } \\
\text { (\%) }\end{array}$ \\
\hline \multirow[t]{4}{*}{1.} & \multirow{3}{*}{$\begin{array}{l}\text { Asam } \\
\text { Asetat 25\% }\end{array}$} & 1 & 0.502 & 0.349 & 30.48 & 0.215 & 57.17 \\
\hline & & 2 & & 0.337 & 32.47 & 0.228 & 54.58 \\
\hline & & 3 & 2 & 0.352 & 29.88 & 0.298 & 40.64 \\
\hline & Rata-rata & & & 0.346 & 31.08 & 0.247 & 50.80 \\
\hline \multirow[t]{4}{*}{2.} & Asam & 1 & 0,502 & 0.409 & 18.53 & 0.382 & 23.90 \\
\hline & Sitrat25\% & 2 & & 0.417 & 16.93 & 0.379 & 24.50 \\
\hline & & 3 & & 0.422 & 15.94 & 0.391 & 22.11 \\
\hline & Rata-rata & & & 0.416 & 17.13 & 0.384 & 23.51 \\
\hline
\end{tabular}


Tabel 2 Kadar Pb pada Daging Kerang Darah

No.

Kadar Pb pada Daging Kerang Darah (ppm)

Setelah Perendaman

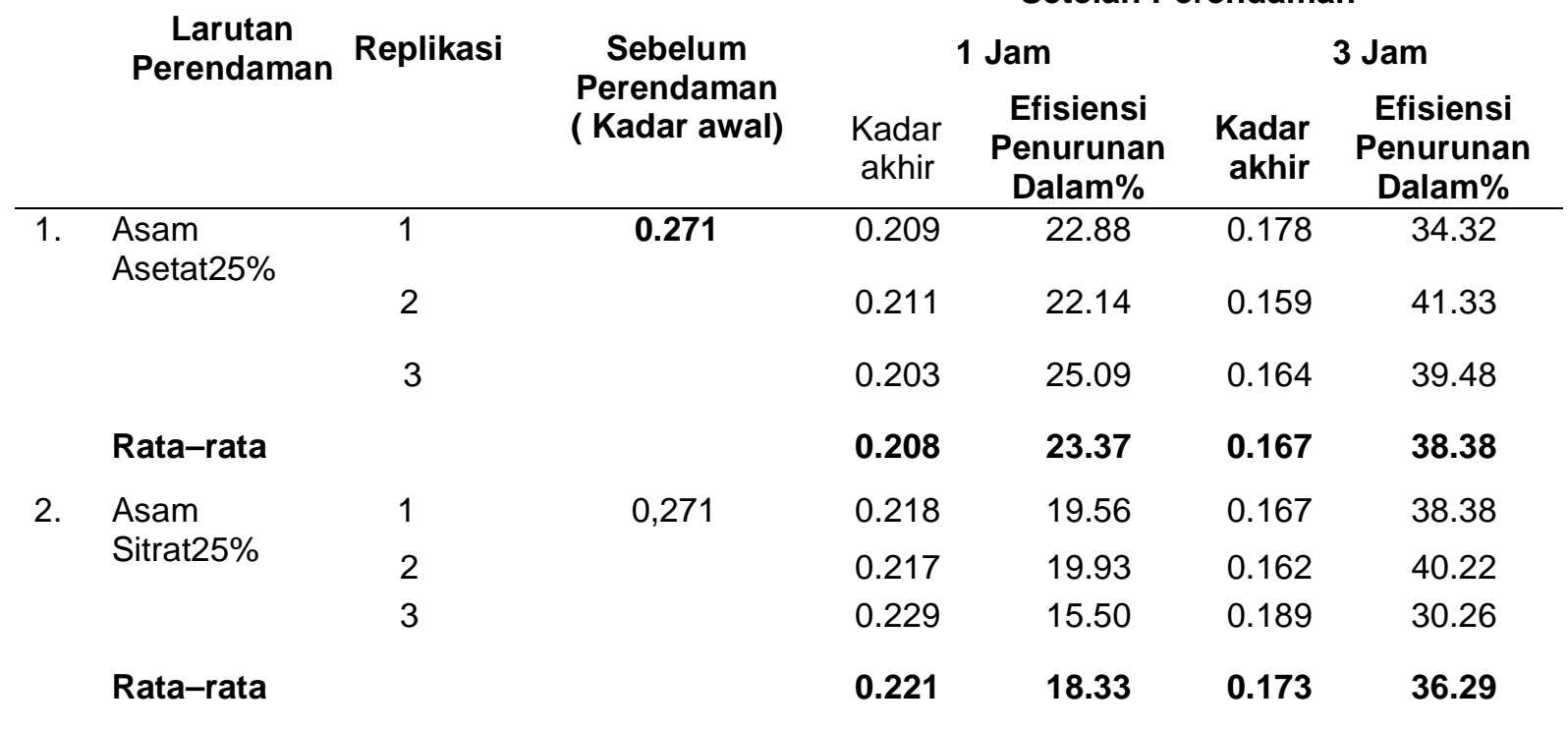

Dari tabel 1 dan 2 dapat dilihat bahwa kerang darah yang berasal dari Pantai Kenjeran Surabaya telah tercemar oleh logam berat timbal $(\mathrm{Pb})$, kadar $\mathrm{Pb}$ mula - mula pada cangkang kerang darah, yakni $0.502 \mathrm{ppm}$, sedangkan kadar $\mathrm{Pb}$ pada daging kerang darah, yakni 0.217 ppm. Kadar $\mathrm{Pb}$ pada kerang masih dalam batas aman $\mathrm{NAB}$ pencemaran $\mathrm{Pb}$ pada makanan, karena batas yang direkomendasikan oleh WHO untuk kadar $\mathrm{Pb}$ pada makanan yang dikonsumsi manusia adalah 0.1 - 2 ppm (Darmono, 2001). Namun apabila kerang dengan kadar $\mathrm{Pb}$ tersebut dikonsumsi manusia secara terus - menerus, maka akan terjadi akumulasi di dalam tubuh anusia. Pada akhirnya toksik pada organ - organ tubuh tertentu, seperti dalam sistem hemopoietik, saraf pusat dan tepi, ginjal, gastro intestinal, kardiovaskuler, reproduksi, serta indokrin.
Ada beda signifikan antara kadar $\mathrm{Pb}$ pada cangkang dan daging kerang darah, rata -rata kadar $\mathrm{Pb}$ pada cangkang lebih besar bila dibandingkan dengan kadar $\mathrm{Pb}$ pada daging kerang darah, hal ini dapat disebabkan karena cangkang kerang darah merupakan bagian terluar atau permukaan organisme yang sedianya kontak langsung dengan perairan laut, karenanya jauh lebih mudah terkontaminasi oleh zat beracun di sekitarnya. Mikroorganisme atau bahan kimia yang terdapat dalam air akan lebih cepat terkonsentrasi di dalamnya.

Pengaruh Jenis Asam dan Waktu Perendaman Terhadap Kadar $\mathrm{Pb}$ Pada Daging Dan Cangkang Kerang Darah

Pengaruh jenis asam sebagai larutan perendam terhadap penurunan kadar $\mathrm{Pb}$ pada cangkang dan daging kerang dapat dilihat pada gambar 1 dan gambar 2 di bawah ini 


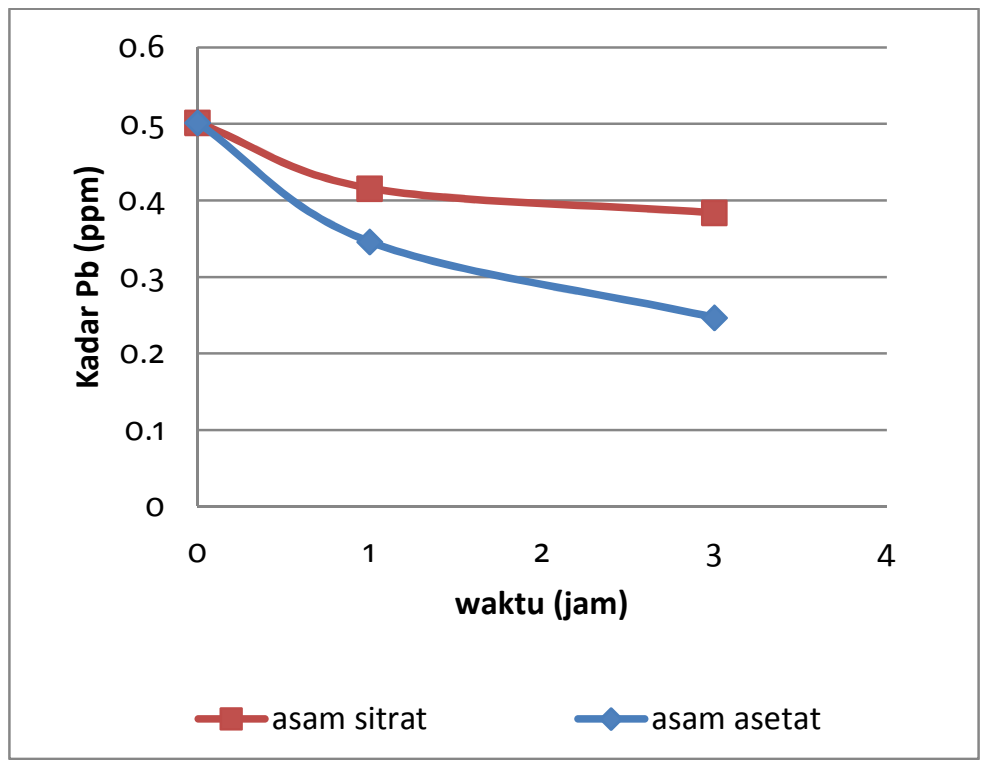

Gambar 1. Pengaruh Larutan Perendam Terhadap Kadar Pb pada Cangkang Kerang

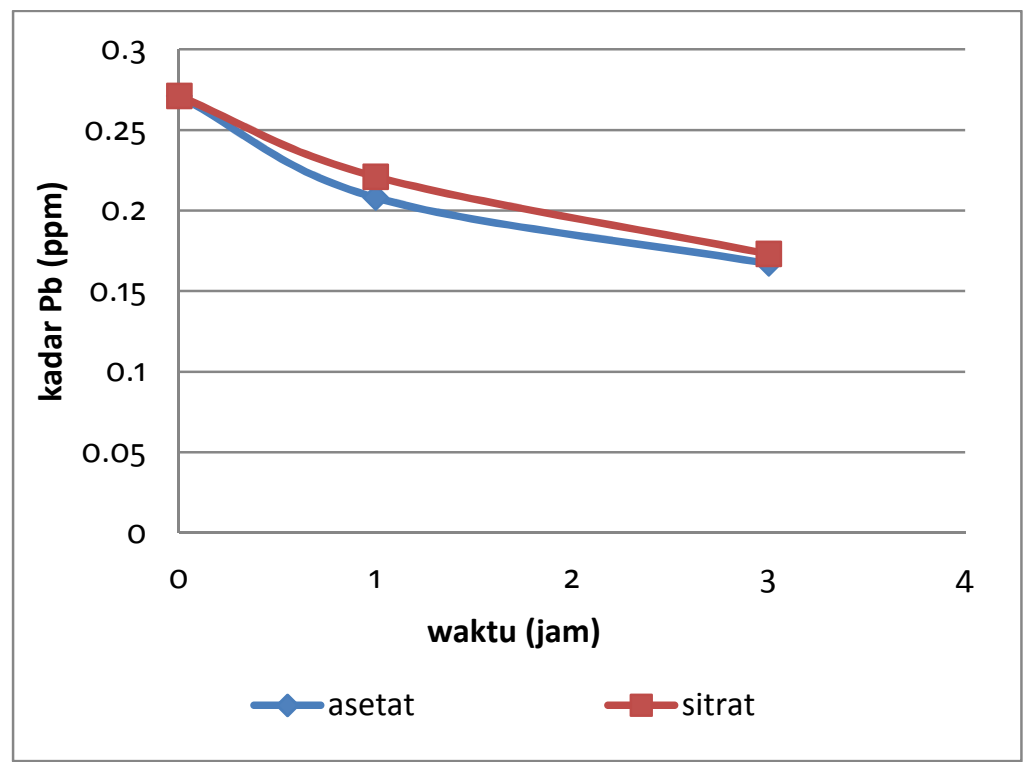

Gambar 2. Pengaruh Larutan Perendam Terhadap Kadar Pb pada Daging Kerang

Dari gambar 1 dan 2 dapat dilihat bahwa daging dan cangkang kerang darah setelah dilakukan perendaman dengan larutan asam, yaitu asetat atau Sitrat $25 \%$ selama 1 dan 3 jam, maka ada beda penurunan signifikan antara perendaman dengan larutan asam asetat atau sitrat 25 $\%$. Untuk mencapai kadar $\mathrm{Pb}$ paling baik dan atau penurunan paling besar, pada perendaman cangkang kerang yakni dengan perendaman larutan asam asetat $25 \%$. Hal ini dikarenakan asam asetat dan asam sitrat sama-sama bersifat asam lemah dan bersifat sebagai pengikat logam berat, tetapi tingkat keasaman kedua asam ini berbeda. Asam asetat mempunyai Pka 4,76 sedangkan asam sitrat merupakan asam poliprotik dengan harga $\mathrm{Pka}_{1}=3.14, \mathrm{Pka}_{2}=4,77$ dan $\mathrm{Pka}_{3}=6,39$. Dengan demikian keasaman asam asetat lebih kuat daripada asam sitrat.

$$
\text { Perendaman daging kerang }
$$
menggunakan asam asetat dan asam sitrat tidak memberikan perbedaan yang signifikan terhadap penurunan kadar $\mathrm{Pb}$. Keadaan ini menunjukan bahwa kesempatan kedua asam tersebut untuk mengikat logam $\mathrm{Pb}$ dalam daging kerang adalah sama. Hal ini kemunginan karena daging kerang bersifat lunak sehingga kesempatan asam asetet dan sitrat untuk mengikat logam itu sama 
kuat.

Semakin lama perendaman dengan larutan asam, mulai dari 1 jam dan 3 jam semakin lama waktu perendaman semakin kecil kadar $\mathrm{Pb}$ dalam daging dan cangkang kerang. Keadaan ini disebabkan karena dengan waktu perendaman yang lama kesempatan kontak antara logam dengan asam juga semakin lama, sehingga asam mempunyai kesempatan yang lama untuk mengikat logam.

Potensi pencemaran lingkungan oleh limbah $\mathbf{P b}$ Yang Berasal Dari Limbah Cangkang Kerang Darah

Kadar logam berat $\mathrm{Pb}$ pada larutan asam setelah digunakan untuk merendam cangkang dan daging kerang darah dapat dilihat pada tabel 3 di bawah ini.

Tabel 3

Kadar Pb pada Larutan Asam Asetat dan Sitrat $25 \%$ Setelah Digunakan Sebagai Media Perendaman Cangkang dan Daging Kerang Darah

No.

Kadar $\mathrm{Pb}$ pada Larutan

Asam Aseta t25\%( ppm)
Kadar Pb pada Larutan

Asam Sitrat25\%( ppm)

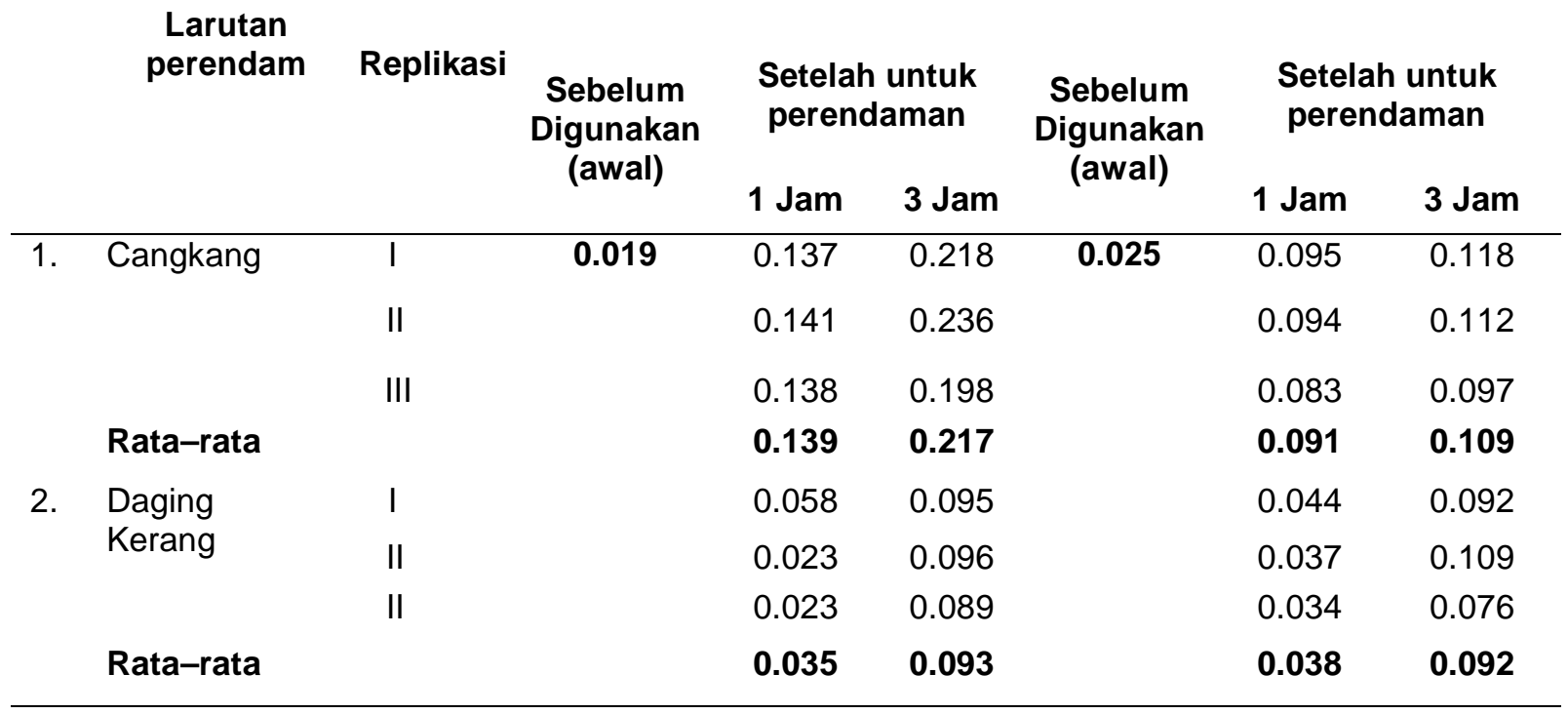

Dari tabel 3 dan gambar 3 dapat dilihat bahwa semakin lama waktu perendaman kadar $\mathrm{Pb}$ yang terkandung larutan asam setelah digunakan untuk merendam cangkang kerang semakin meningkat. Hal ini disebabkan karena semakin lama waktu perendaman semakin banyak kontak antara logam dengan asam oleh karena itu kesempatan asam untuk mengikat logam semakin besar.

Kadar $\mathrm{Pb}$ pada asam asetet setelah digunakan untuk merendam cangkang kerang lebih tinggi dari pada kadar $\mathrm{Pb}$ yang terkandung dalam asam sitrat. Keadaan ini juga seiring dengan semakin kuat asam asetat dalam mengikat logam $\mathrm{Pb}$ sehingga kadar $\mathrm{Pb}$ dalam larutan asam asetat juga semakin tinggi.

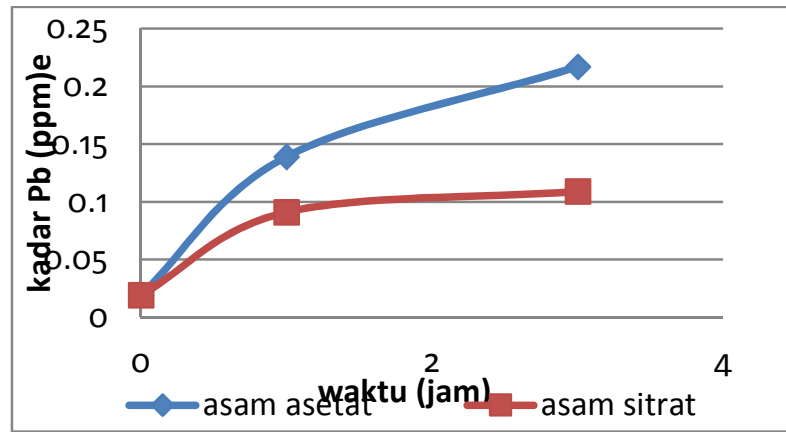

Gambar 3. Kadar Pb Pada Larutan Asam Setelah Digunakan Untuk Merendam Cangkang Kerang 
Dari gambar 4 terlihat bahwa kadar logam $\mathrm{Pb}$ dalam asam asetat dan sitrat setelah digunakan untuk merendam daging kerang darah tidak berbeda secara signifikan. Keadaan ini menunjukan bahwa kesempatan kedua asam tersebut untuk mengikat logam $\mathrm{Pb}$ dalam daging kerang adalah sama. Hal ini kemunginan karena daging kerang bersifat lunak sehingga kesempatan asam asetet dan sitrat untuk mengikat logam itu sama kuat. Semakin lama waktu perendaman kadar logam $\mathrm{Pb}$ dalam asam juga semakin tinggi.

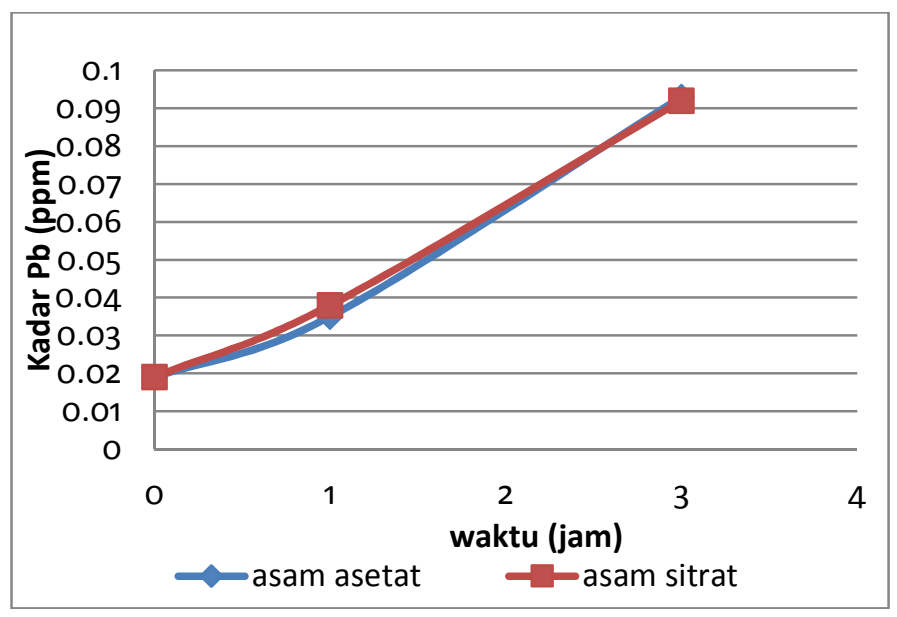

Gambar 4. Kadar Pb Pada Larutan Asam Setelah Digunakan Untuk Merendam Daging Kerang

\section{Potensi Pencemaran $\mathrm{Pb}$ yang diakibatkan dari Limbah Cangkang Kerang}

Jumlah sampel kerang darah yang dibeli dari penjual atau pedagang kerang di daerah Pantai Kenjeran Surabaya sebanyak $10 \mathrm{~kg}$. Kerang darah kemudian dipisahkan antara cangkang dan dagingnya. Dari berat $10 \mathrm{~kg}$ kerang darah, $7.2 \mathrm{~kg}$ merupakan berat cangkang, sedangkan sisanya $2.8 \mathrm{~kg}$ merupakan berat daging. Berat cangkang kerang darah kurang lebih $72 \%$ dari berat keseluruhan ( cangkang dan daging ).

Berdasarkan hasil pemeriksaan laboratorium dalam penelitian ini, kadar $\mathrm{Pb}$ untuk $7.2 \mathrm{~kg}$ cangkang kerang darah ( per 250 gr sampel ), yakni 0.502 ppm, sedangkan rata - rata kadar $\mathrm{Pb}$ dalam cangkang kerang darah setelah perendaman dengan larutan asam asetat $25 \%$ selama 1 dan 3 jam, menjadi $0.346 \mathrm{ppm}$ dan $0.247 \mathrm{ppm}$, dengan larutan asam sitrat $25 \%$ selama 1 dan 3 jam, menjadi 0.416 ppm dan 0.384 ppm.

Menurut informasi penjual kerang di daerah Pantai Kenjeran Surabaya, total produksi kerang darah per tahun kurang lebih mencapai 1400 ton atau $1400000 \mathrm{~kg}$. Karenanya dapat diperkirakan akan dihasilkan limbah cangkang kerang darah sebanyak 1008000 kg. Daging kerang darah umumnya dikonsumsi masyarakat. Oleh karena itu, dapat diperkirakan konsentrasi pencemaran $\mathrm{Pb}$ oleh limbah cangkang kerang darah pada penjual kerang per tahun mula - mula kurang lebih sebesar 70280 ppm. Jika penjual melakukan perendaman larutan asam asetat $25 \%$ selama 1 dan 3 jam, maka konsentrasi pencemaran $\mathrm{Pb}$ oleh limbah cangkang kerang darah kurang lebih sebesar 48440 ppm dan 34580 ppm, sedangkan jika melakukan perendaman larutan asam sitrat $25 \%$ selama 1 dan 3 jam, maka konsentrasi pencemaran $\mathrm{Pb}$ oleh limbah cangkang kerang kerang darah kurang sekitar sebesar 58240 ppm dan 53760 ppm.

Nilai pencemaran tersebut cukup tinggi, sehingga dapat membahayakan lingkungan sekitar, karena konsentrasi $\mathrm{Pb}$ yang mencapai 188 ppm kebadanperairan, dapat membunuh ikan - ikan yang ada di dalamnya.

\section{Pencemaran $\mathrm{Pb}$ Ke Lingkungan Yang Berasal Dari Larutan Perendaman Atau Larutan Asam}

Penggunaan larutan asam asetat atau sitrat $25 \%$ di atas terbukti dapat menurunkan kadar logam berat $\mathrm{Pb}$ pada kerang darah, namun penggunaan larutan 
asam tersebut tidak lepas dari dampak pencemaran $\mathrm{Pb}$ baru ke lingkungan, karena terjadi pengikatan kadar $\mathrm{Pb}$ oleh masing - masing larutan asam asetat dan sitrat $25 \%$. Kadar $\mathrm{Pb}$ pada larutan asam asetat $25 \%$ setelah digunakan merendam cangkang selama 1 dan 3 jam, masing-masing yaitu $0.139 \mathrm{ppm}$ dan 0.217 ppm, setelah digunakan merendam daging kerang darah, masing- masing yaitu 0.035 ppm dan $0.093 \mathrm{ppm}$, sedangkan kadar $\mathrm{Pb}$ dalam larutan asam sitrat $25 \%$ setelah digunakan merendam cangkang selama 1 dan 3 jam, masing - masing yaitu 0.091 ppm dan 0.109 ppm, setelah digunakan merendam daging kerang darah, masing masing yaitu $0.038 \mathrm{ppm}$ dan $0.092 \mathrm{ppm}$.

Perlunya dilakukan pengolahan limbah cair lanjutan terhadap media perendaman larutan asam yang digunakan penjual kerang, karena pencemaran $\mathrm{Pb}$ baru ke media lingkungan tidak mustahil dapat mengganggu keseimbangan lingkungan, mengakibatkan gangguan kesehatan, menimbulkan gangguan estetika, seperti bau busuk, serta dapat merusak benda - benda lain di sekitarnya, hal ini mengingat asam bersifat korosif terhadap banyak logam, seperti besi, magnesium, dan seng.

\section{KESIMPULAN}

Dari penelitian ini dapat disimpulkan :

1. Kadar $\mathrm{Pb}$ mula - mula pada cangkang kerang darah, yakni 0.502 ppm, setelah perendaman dengan larutan asam asetat $25 \%$ selama 1 dan 3 jam, rata - rata kadar $\mathrm{Pb}$ menjadi $0.346 \mathrm{ppm}$ dan $0.247 \mathrm{ppm}$, dengan larutan asam sitrat rata - rata kadar $\mathrm{Pb}$ menjadi 0.416 ppm dan 0.384 ppm.

Kadar $\mathrm{Pb}$ mula - mula pada daging kerang darah, yakni $0.217 \mathrm{ppm}$, setelah perendaman dengan larutan asam asetat $25 \%$ selama 1 dan 3 jam, rata - rata kadar $\mathrm{Pb}$ menjadi 0.208 ppm dan 0.167 ppm, dengan larutan asam sitrat rata - rata kadar $\mathrm{Pb}$ menjadi $0.221 \mathrm{ppm}$ dan $0.173 \mathrm{ppm}$.

2. Ada beda penurunan signifikan antara perendaman dengan larutan asam asetat atau sitrat $25 \%$, mencapai kadar $\mathrm{Pb}$ paling baik dan atau penurunan paling besar, yakni dengan perendaman larutan asam asetat $25 \%$.

3. Semakin lama perendaman dengan larutan asam, semakin besar pula penurunan kadar $\mathrm{Pb}$ pada cangkang dan daging kerang darah, ada beda signifikan antara lama perendaman 1 dan 3 jam, mencapai kadar $\mathrm{Pb}$ paling baik dan atau penurunan paling besar, yakni dengan oleh lama perendaman 3 jam.

4. Cangkang kerang darah dan larutan asam bekas perendaman berpotensi mencemari air dan tanah yang digunakan untuk membuang limbah tersebut.

\section{SARAN}

Dari hasil penelitian ini disarankan :

1. Masyarakat dapat melakukan perendaman daging kerang darah dengan larutan asam asetat $25 \%$ selama 3 jam untuk menurunkan kadar logam berat $\mathrm{Pb}$ pada kerang sebelum dicuci atau dimasak.

2. Jika penjual atau pedagang kerang menggunakan larutan asam asetat atau sitrat $25 \%$ untuk menurunkan kadar logam berat $\mathrm{Pb}$ pada kerang darah, sedianya penjual kerang tersebut perlu melakukan pengolahan limbah cairnya

3. Limbah cangkang kerang darah sebelum atau setelah perendaman dengan larutan asam asetat atau sitrat $25 \%$, sebaiknya tidak dibuang kembali ke laut atau badan perairan, serta media lingkungan lainnya, karena dapat menambah beban pencemaran logam berat $\mathrm{Pb}$ di lingkungan.

4. Perlu adanya penelitian lebih lanjut untuk mengetahui sejauh mana pengaruh perendaman larutan asam terhadap logam berat lainnya atau cita rasa, serta kandungan gizi kerang, terutama protein yang terkandung di dalamnya.

5. Perlu ada penelitian Ianjutan, tentang pengaruh media perendaman yang lain dan konsentrasi dan waktu yang berbeda sehingga dapat mengetahui waktu optimum yang dibutuhkan, sehingga dapat menurunkan kadar logam berat kerang sampai dengan 0 ( nol).

6. Perlu adanya pengawasan atau pengendalian pencemaran logam berat $\mathrm{Pb}$ oleh pihak - pihak terkait di hulu Pantai Kenjeran Surabaya, sehingga dapat dicegah adanya peningkatan kadar $\mathrm{Pb}$ pada biota laut, diantaranya 


\section{DAFTAR PUSTAKA}

Anonymous, 2007. Monitoring Sanitasi Kekerangan oleh Dinas Kelautan dan Perikanan Provinsi Jawa Timur. Sucofindo, Surabaya.

Bajuri, 2003. Perbedaan Kadar Pb dalam Kupang dengan Jenis Kupang Awung(Mytilus Viridis) dan Kupang Jawa (Musculista Senhausia). Skripsi Universitas Airlangga, Surabaya.

Darmono, 2001. Lingkungan Hidup dan Pencemaran (Hubungannya dengan Toksikologi Senyawa Logam). UI-Perss, Jakarta.

FAO / WHO, 1980. Recommended Health - Based Limit in Occupational Exposure to Heavy Metal. World Health Organization, Geneva.

Imaduddin, Saiful dan Soedjajadi Keman, 2000. Kemampuan Larutan Asam Asetat $25 \%$ terhadap Penurunan Kadar Logam Berat Pb dalam Daging Ikan Bandeng (Chanos Forsk). Forum Ilmu Kesehatan Masyarakat.

Inswiasri dkk, 1995. Kandungan Logam Kadmium dalam Biota Laut Jenis Kerang - kerangan dari Teluk Jakarta. Pusat Penelitian Ekologi Kesehatan, Badan Penelitian dan Pengembangan Kesehatan Departemen Kesehatan RI, Jakarta.

Kronkvist, B., 2006. Prevalence of Faecal Indicator Organisms and Human Bacterial Pathogens in Bivalves from Maputo Bay, Mozambique. Thesis Departement of Mathematics and Natural Sciences - Kristianstad University, Sweden.

Nontji, Anugerah, 2002. Laut Nusantara. Djambatan, Jakarta.

Nuraini, Anis dan Lilis S., 2006. Perbandingan Penurunan Kadar Pb pada Kupang Awung (Mytilus Viridis) dengan Menggunakan Perendaman Asam Cuka $25 \%$ dan Aqua. Jurnal Kesehatan Lingkungan FKM Universitas Airlangga, Surabaya.

Palar, Heryanto, 2004. Pencemaran dan Toksikologi Logam Berat. Rineka Cipta, Jakarta

Pikir, Suharno, 1993. Sedimen dan Kerang sebagai Indikator Adanya Logam Berat Cd, Hg, dan $\mathrm{Pb}$ dalam Pencemaran di Lingkungan Estuari. Disertasi Pascasarjana Universitas Airlangga, Surabaya.

Rahardhiman, Aryatama, 2008. Penurunan kadar Pb pada Kupang Awung (Mytilus Viridis) dengan Menggunakan Perendaman Asam Sitrat. Karya Tulis IImiah Kesehatan Lingkungan Poltekkes Depkes, Surabaya. 